\title{
HÆMODYNAMIC CHANGES IN CHRONIC CONSTRICTIVE PERICARDITIS DURING EXERCISE AND HISTAMINE INFUSION
}

\author{
BY \\ S.-E. LINDELL, A. SVANBORG, B. SÖDERHOLM, AND H. WESTLING \\ From the Department of Clinical Physiology and the Medical Clinic II, University of Göteborg, Sweden
}

Received January 22, 1962

It is generally agreed that the important hæmodynamic effect of chronic constrictive pericarditis consists of mechanical limitation to ventricular filling and possibly also to emptying (Zimmerman, 1959; Wood, 1961). Several measurements have shown the cardiac output and the stroke volume in constrictive pericarditis to be low at rest and during exercise (Johansson, 1958).

In the course of studies on the effect of histamine on pulmonary ventilation and circulation in heart and lung disease, we examined four men with chronic constrictive pericarditis. The diagnosis was verified at operation in all cases. Heart catheterization was performed and observations made of the hæmodynamics at rest, during a work load, and during an intravenous infusion of histamine. Apart from effects on the pulmonary circulation, histamine caused a conspicuous increase in the cardiac output and stroke volume in these cases. This effect of histamine may, apart from its pharmacological interest, contribute to our understanding of the hæmodynamic changes in constrictive pericarditis. For this reason a separate description seems warranted.

\section{METHODS}

The heart catheterizations were performed in the morning after a light meal. A double lumen catheter (no. 9) was wedged in a pulmonary artery (PCV position) with the proximal lumen in the pulmonary artery. Another catheter (no. 6) was introduced into the right atrium. Brachial arterial pressure was recorded from an indwelling polythene tube (Bernéus et al., 1954). Pressures were recorded with strain-gauge manometers on a six-channel direct writing recorder (Mingograph, Elema). A point $5 \mathrm{~cm}$. dorsal to the sternal angle was used as zero reference level. Mean pressures were measured by planimetrical integration. Cardiac output was estimated according to Fick's direct principle. Gas analysis and measurements of oxygen saturation and oxygen capacity were performed as described by Söderholm (1957). Arterial carbon dioxide tension was measured as described by Carlsten and Söderholm (1960). The alveolar-arterial difference in oxygen tension was calculated from the alveolar air equation and the Dill curve (Rahn and Fenn, 1955).

Pressures and flows were studied in the supine position at rest, during exercise on a bicycle ergometer $(200 \mathrm{kp} \mathrm{m} / \mathrm{min}$.), and during a continuous intravenous infusion of histamine in a dose which was chosen so as to cause moderate circulatory effects (tachycardia and facial flushing). All measurements were made under steady state conditions as judged by pulse rates and pressures. Spirometry was performed with a modified Bernstein spirometer (Grimby and Söderholm, 1963). Blood volume and total hæmoglobin were measured with radioactive chromium as described by Arenander et al. (1962).

\section{CASE REPORTS}

Case 1. A truck driver, 48 years old and previously in good health, noticed general weakness and dyspnœa on exertion in February 1959. Some months later anorexia, epigastric pains, and a feeling of fullness in the abdomen on exertion developed. Because of the abdominal symptoms he was sent to a surgical 
clinic. The liver was enlarged and a malignant process in the abdomen was suspected. However, at laparotomy the only pathological finding was the enlargement of the liver, and a biopsy showed a slight increase of fibrous tissue, supposed to be a sign of early portal cirrhosis. A radiogram of the chest showed pericardial calcifications, and he was transferred to the medical clinic. At that time he had dyspnœa at rest, œdema in the extremities, and slight cyanosis. Præcordial systolic retraction, venous engorgement in the neck, and a third heart sound were demonstrated. The electrocardiogram showed sinus rhythm and some flattening of the $\mathrm{T}$ waves. Further data are given in Table $\mathrm{I}$. The patient was not digitalized or treated with diuretics at the catheterization.

TABLE I

Physiological Characteristics of Four Cases of Constrictive Pericarditis

\begin{tabular}{c|c|c|c|c|c|c|c|c}
\hline $\begin{array}{c}\text { Case } \\
\text { No. }\end{array}$ & $\begin{array}{c}\text { Age } \\
\text { (yr.) }\end{array}$ & $\begin{array}{c}\text { Height } \\
\text { (cm.) }\end{array}$ & $\begin{array}{c}\text { Weight } \\
\text { (kg.) }\end{array}$ & $\begin{array}{c}\text { Heart volume } \\
\text { (ml./m2. } \\
\text { B.S.A.) }\end{array}$ & $\begin{array}{c}\text { Total blood } \\
\text { volume } \\
(1 .)\end{array}$ & $\begin{array}{c}\text { Total } \\
\text { hæmoglobin } \\
(\mathbf{g} .)\end{array}$ & $\begin{array}{c}\text { Vital* } \\
\text { capacity } \\
(1 .)\end{array}$ & $\begin{array}{c}\text { F.E.V. } \\
1.0 / \text { V. } \\
(\%)\end{array}$ \\
\hline 1 & 48 & 164 & 59 & 485 & $5 \cdot 0$ & 660 & $3 \cdot 7(3 \cdot 9)$ & $68(71)$ \\
2 & 56 & 174 & 65 & 800 & $7 \cdot 7$ & 1040 & $4 \cdot 2(4 \cdot 4)$ & $72(71)$ \\
3 & 68 & 179 & 78 & 550 & $6 \cdot 6$ & 740 & $4 \cdot 7(4 \cdot 4)$ & $71(67)$ \\
4 & 62 & 163 & 64 & 540 & $4 \cdot 8$ & 500 & $2 \cdot 0(3 \cdot 8)$ & $75(69)$ \\
\hline
\end{tabular}

* Predicted normal values are given in parenthesis.

$\dagger$ Forced expired volume in 1 second as percentage of vital capacity.

Pericardiectomy was performed in June 1960. Considerable thickening and calcifications of the pericardium were found with fibrous adhesions to the myocardium and surrounding tissues. Epicardiolysis and resection of the pericardial scar from the anterior and lateral surfaces of the heart were performed. The ventricles were judged to be of normal size.

Case 2. A male housekeeper, 56 years old, had been in good health until 1940 when short attacks of irregular heart rhythm developed. In 1954 he consulted a physician because of slight præcordial pains. The arterial blood pressure was found to be $110 / 80 \mathrm{~mm}$. $\mathrm{Hg}$ and a chest radiogram revealed calcifications in the pericardium. The heart volume was $540 \mathrm{ml} . / \mathrm{m} .{ }^{2}$ body surface area. At that time there were no symptoms of congestive failure but during the following years dyspnœa on exertion developed. In 1960 he was aware of an abnormal feeling of fullness in the abdomen on exertion, and he was admitted to the hospital. The liver was found to be enlarged and a third heart sound was present. The cardiogram showed atrial fibrillation and inverted T waves in leads II, III, AVF, and CR7. Further data are given in Table I. The patient was not digitalized or treated with diuretics at the catheterization.

Pericardiectomy was performed in October 1960. The findings were principally the same as in Case 1. The ventricles and the right atrium were judged to be of normal size but the left atrium seemed to be enlarged. There was thus a discrepancy between the surgeon's and the radiologist's estimate of the heart volume.

Case 3. A salesman, 68 years old and earlier in good health, had intermittent œedema in the legs and abnormal dyspncea on exertion since 1950. In 1960 these symptoms increased, and he was admitted to hospital. He was found to have slight dyspnœa at rest, œdema of the legs, slight cyanosis, a systolic retraction in the præcordial region, a third heart sound, and enlargement of the liver. The cardiogram showed atrial fibrillation and biphasic $\mathrm{T}$ waves in all leads. Further data are given in Table I. Before the catheterization the patient had been fully digitalized and treated with diuretics; this resulted in a pronounced weight loss and a disappearance of visible odema.

Pericardiectomy was performed in December 1960. The findings were principally the same as in Case 1. The heart was judged to be of normal size.

Case 4. A carpenter, 62 years old, had a bilateral pleuritis in 1917, which was thought to be of tuberculous origin. The records from the hospital at that time are not available. In 1950 a routine radiological examination of the chest demonstrated a slight increase of the heart volume. In 1958 dyspnoa on exertion and œdema of the legs appeared, and these symptoms gradually increased. Feeling of fullness in the abdomen and epigastric pains, especially after exercise, developed in 1960 and he had to give up his ordinary work. During the following year the symptoms of congestive failure progressed despite treatment with digitoxin and diuretics. He was admitted to this hospital for further study. At the clinical examination venous engorgement, increased liver size, præcordial systolic retraction, and a third heart sound were ob- 
served. The cardiogram showed atrial fibrillation and inverted T waves in leads AVF, CR1, and CR2. Before the heart catheterization the patient was fully digitalized and treated with diuretics which resulted in a loss of weight and disappearance of visible œdema. Further relevant data are given in Table I.

Pericardiectomy was performed in June 1961. The pericardium was thickened and adherent to the epicardium, to the myocardium, and to surrounding tissues. Extensive calcifications were present in the pericardial scar over the left ventricle and over both atria but not over the right ventricle.

\section{RESULTS}

The results are given in Tables II-IV. Already at rest two subjects (Cases 3 and 4) had signs of an insufficient circulation in the form of a low cardiac output and an increased arteriovenous oxygen difference. The stroke volume was small in all four cases. The mean pressures in the right atrium were considerably raised (14 to $23 \mathrm{~mm}$. Hg) with a similar rise of the PCV pressures (18 to $25 \mathrm{~mm}$. $\mathrm{Hg}$ ). The pulmonary artery pressures were also elevated but the pulmonary vascular resistances were normal or only slightly increased. The pressures in the brachial artery were essentially normal.

TABLE II

HemOdYNAMIC OBSERVATIONS

\begin{tabular}{|c|c|c|c|c|c|c|c|c|c|c|c|c|c|c|c|c|c|c|}
\hline & \multirow{3}{*}{\multicolumn{2}{|c|}{ Case }} & & \multicolumn{10}{|c|}{ Pressures } & \multirow[b]{3}{*}{ SVR } & \multirow[b]{3}{*}{ PVR } & \multirow[b]{3}{*}{$\mathrm{CO}$} & \multirow[b]{3}{*}{ HR } & \multirow[b]{3}{*}{ SV } \\
\hline & & & & \multicolumn{3}{|c|}{ Brachial artery } & \multirow{2}{*}{$\frac{P C V}{M}$} & \multicolumn{3}{|c|}{ Pulm. artery } & \multicolumn{2}{|c|}{$\begin{array}{c}\text { Right } \\
\text { ventricle }\end{array}$} & \multirow[b]{2}{*}{ RA } & & & & & \\
\hline & & & & $\mathbf{S}$ & D & $\mathbf{M}$ & & $\mathbf{S}$ & D & $\mathbf{M}$ & $\mathbf{S}$ & $\mathrm{D}^{*}$ & & & & & & \\
\hline 1 & $\begin{array}{l}\text { Rest } \\
\text { Histamine } \\
\text { Exercise }\end{array}$ & $\begin{array}{l}\cdots \\
\cdots \\
\cdots\end{array}$ & $\begin{array}{l}\ldots \\
\cdots \\
\cdots\end{array}$ & $\begin{array}{l}150 \\
142 \\
175\end{array}$ & $\begin{array}{l}95 \\
92 \\
99\end{array}$ & $\begin{array}{l}125 \\
110 \\
130\end{array}$ & $\begin{array}{l}25 \\
27 \\
34\end{array}$ & $\begin{array}{l}51 \\
45 \\
75\end{array}$ & $\begin{array}{l}29 \\
31 \\
37\end{array}$ & $\begin{array}{l}40 \\
39 \\
57\end{array}$ & $\frac{52}{-}$ & $\begin{array}{l}7-30 \\
-\end{array}$ & $\begin{array}{l}23 \\
20 \\
28\end{array}$ & $\begin{array}{l}20 \cdot 6 \\
13 \cdot 0 \\
16 \cdot 0\end{array}$ & $\begin{array}{l}3 \cdot 0 \\
1 \cdot 7 \\
3 \cdot 6\end{array}$ & $\begin{array}{l}4 \cdot 96 \\
6 \cdot 94 \\
6 \cdot 36\end{array}$ & $\begin{array}{r}79 \\
90 \\
100\end{array}$ & $\begin{array}{l}63 \\
77 \\
64\end{array}$ \\
\hline 2 & $\begin{array}{l}\text { Rest } \\
\text { Histamine } \\
\text { Exercise }\end{array}$ & $\begin{array}{l}\ldots \\
\cdots \\
\cdots\end{array}$ & $\begin{array}{l}\ldots \\
\cdots \\
\ldots\end{array}$ & $\begin{array}{l}121 \\
125 \\
151\end{array}$ & $\begin{array}{l}85 \\
85 \\
94\end{array}$ & $\begin{array}{r}99 \\
107 \\
123\end{array}$ & $\begin{array}{l}18 \\
24 \\
38\end{array}$ & $\begin{array}{l}28 \\
35 \\
50\end{array}$ & $\begin{array}{l}16 \\
18 \\
28\end{array}$ & $\begin{array}{l}22 \\
24 \\
42\end{array}$ & $\frac{30}{-}$ & $\begin{array}{l}3-15 \\
-\end{array}$ & $\begin{array}{l}16 \\
14 \\
34\end{array}$ & $\begin{array}{l}16 \cdot 3 \\
14 \cdot 0 \\
17 \cdot 0\end{array}$ & $\begin{array}{r}0.8 \\
<0.1 \\
0.8\end{array}$ & $\begin{array}{l}5 \cdot 10 \\
6 \cdot 65 \\
5 \cdot 36\end{array}$ & $\begin{array}{r}97 \\
96 \\
105\end{array}$ & $\begin{array}{l}53 \\
69 \\
51\end{array}$ \\
\hline 3 & $\begin{array}{l}\text { Rest } \\
\text { Histamine } \\
\text { Exercise }\end{array}$ & $\begin{array}{l}\cdots \\
\cdots \\
\cdots\end{array}$ & $\begin{array}{l}\ldots \\
\cdots \\
\ldots\end{array}$ & $\begin{array}{l}141 \\
119 \\
170\end{array}$ & $\begin{array}{l}81 \\
70 \\
98\end{array}$ & $\begin{array}{r}100 \\
81 \\
125\end{array}$ & $\begin{array}{l}20 \\
24 \\
39\end{array}$ & $\begin{array}{l}47 \\
49 \\
72\end{array}$ & $\begin{array}{l}24 \\
28 \\
31\end{array}$ & $\begin{array}{l}30 \\
37 \\
47\end{array}$ & $\frac{45}{-}$ & $\begin{array}{l}3-15 \\
-\end{array}$ & $\begin{array}{l}17 \\
14 \\
21\end{array}$ & $\begin{array}{l}24 \cdot 8 \\
11 \cdot 1 \\
24 \cdot 5\end{array}$ & $\begin{array}{l}3 \cdot 0 \\
2 \cdot 1 \\
1 \cdot 9\end{array}$ & $\begin{array}{l}3 \cdot 35 \\
6 \cdot 05 \\
4 \cdot 25\end{array}$ & $\begin{array}{l}54 \\
66 \\
78\end{array}$ & $\begin{array}{l}62 \\
92 \\
54\end{array}$ \\
\hline 4 & $\begin{array}{l}\text { Rest } \\
\text { Histamine } \\
\text { Exercise } \\
\text { Venesection }\end{array}$ & $\begin{array}{l}\cdots \\
\cdots \\
\cdots\end{array}$ & $\begin{array}{l}\ldots \\
\ldots \\
\ldots \\
\ldots\end{array}$ & $\begin{array}{l}136 \\
120 \\
169 \\
104\end{array}$ & $\begin{array}{l}80 \\
68 \\
83 \\
59\end{array}$ & $\begin{array}{r}104 \\
81 \\
111 \\
78\end{array}$ & $\begin{array}{r}22 \\
16 \\
31 \\
9\end{array}$ & $\begin{array}{l}44 \\
35 \\
86 \\
26\end{array}$ & $\begin{array}{r}18 \\
14 \\
34 \\
7\end{array}$ & $\begin{array}{l}26 \\
21 \\
49 \\
12\end{array}$ & $\begin{array}{l}\text { - } \\
\text { - }\end{array}$ & $\begin{array}{l}6-15 \\
- \\
-\end{array}$ & $\begin{array}{r}14 \\
9 \\
25 \\
5\end{array}$ & $\begin{array}{l}22 \cdot 2 \\
11 \cdot 0 \\
13 \cdot 8 \\
20 \cdot 4\end{array}$ & $\begin{array}{l}1.0 \\
0.8 \\
2.9 \\
0.8\end{array}$ & $\begin{array}{l}4 \cdot 04 \\
6 \cdot 57 \\
6 \cdot 24 \\
3 \cdot 58\end{array}$ & $\begin{array}{r}76 \\
92 \\
102 \\
64\end{array}$ & $\begin{array}{l}53 \\
71 \\
61 \\
56\end{array}$ \\
\hline
\end{tabular}

All pressures are given in $\mathrm{mm}$. $\mathrm{Hg}$.

$\mathrm{S}=$ Systolic

$\mathrm{D}=$ Diastolic

$M=$ Mean

$\mathrm{PCV}=$ Pulmonary artery wedge pressure

* Right ventricular diastolic pressure measured early and late in diastole

$\mathbf{R A}=\mathbf{R}$ ight atrium
$\mathrm{SVR}=$ Systemic vascular resistance $\frac{\left(\overline{\mathrm{P}}_{\mathrm{BA}}-\overline{\mathrm{P}}_{\mathrm{RA}}\right)}{\mathrm{CO}}$

$\mathbf{P V R}=$ Pulmonary vascular resistance $\frac{(\overline{\mathbf{P}} \mathbf{P A}-\overline{\mathbf{P}} \mathbf{P C V})}{\mathbf{C O}}$

$\mathrm{CO}=$ Cardiac output $(1 . / \mathrm{min}$.)

$\mathrm{HR}=$ Heart rate

$\mathrm{SV}=$ Stroke volume $(\mathrm{ml}$.)

The oxygen saturation of arterial blood was within the normal range and the carbon dioxide tension was low or normal. There were thus no obvious signs of insufficient ventilation of the lungs. The calculated difference in oxygen tension between alveoli and arterial blood ([A-a $] \mathrm{O}_{2}$ difference) was normal in Case 2 (less than $4 \mathrm{~mm}$. $\mathrm{Hg}$ ). In Cases 1, 3, and 4 the differences were 25, 15, and $12 \mathrm{~mm}$. $\mathrm{Hg}$, respectively, possibly indicating abnormal ventilation-perfusion relations.

A work load of $200 \mathrm{kp} \mathrm{m} / \mathrm{min}$., which increased the oxygen consumption to 500-700 ml. per min., was in all cases associated with an inadequate increase in cardiac output, and no consistent change in 
TABLE III

RESPIRATORY OBSERVATIONS

\begin{tabular}{|c|c|c|c|c|c|c|c|c|c|c|c|c|}
\hline Case & & $\mathrm{SaO}_{2}$ & $\mathrm{O}_{2}$ cap & $(\mathrm{A}-\mathrm{v}) \mathrm{O}_{2}$ & $\dot{\mathrm{V}}_{2}$ & $\dot{\mathrm{V}} \mathrm{E}$ & $\dot{\mathbf{V}} \mathbf{A}$ & RF & $\mathrm{PaCO}_{2}$ & pH & $(\mathrm{A}-\mathrm{a}) \mathrm{O}_{2}$ & $\Delta \mathrm{p}$ \\
\hline $1 \underset{\text { Hest }}{\text { Histamine }}$. & $\begin{array}{l}. \\
. \\
.\end{array}$ & $\begin{array}{l}94 \cdot 4 \\
87 \cdot 6 \\
91 \cdot 2\end{array}$ & $\begin{array}{l}17 \cdot 4 \\
17 \cdot 8 \\
18 \cdot 1\end{array}$ & $\begin{array}{l}46 \\
31 \\
94\end{array}$ & $\begin{array}{l}228 \\
215 \\
598\end{array}$ & $\begin{array}{r}7 \cdot 5 \\
7 \cdot 9 \\
18 \cdot 6\end{array}$ & $\begin{array}{r}4 \cdot 0 \\
4 \cdot 5 \\
11 \cdot 1\end{array}$ & $\begin{array}{l}16 \\
18 \\
22\end{array}$ & $\begin{array}{l}43 \\
37 \\
42\end{array}$ & $\begin{array}{l}7 \cdot 40 \\
7 \cdot 42 \\
7 \cdot 36\end{array}$ & $\begin{array}{l}25 \\
54 \\
39\end{array}$ & $\begin{array}{l}5 \\
9 \\
9\end{array}$ \\
\hline 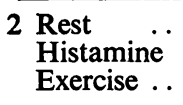 & $\begin{array}{l}\cdots \\
\cdots \\
\cdots\end{array}$ & $\begin{array}{l}98 \cdot 9 \\
95 \cdot 3 \\
99 \cdot 1\end{array}$ & $\begin{array}{l}18 \cdot 3 \\
18 \cdot 5 \\
19 \cdot 5\end{array}$ & $\begin{array}{r}49 \\
37 \\
111\end{array}$ & $\begin{array}{l}250 \\
246 \\
595\end{array}$ & $\begin{array}{r}8 \cdot 6 \\
8 \cdot 3 \\
18 \cdot 2\end{array}$ & $\begin{array}{r}5 \cdot 7 \\
5 \cdot 4 \\
13 \cdot 7\end{array}$ & $\begin{array}{r}9 \\
10 \\
15\end{array}$ & $\begin{array}{l}33 \\
32 \\
32\end{array}$ & $\begin{array}{l}7 \cdot 40 \\
7 \cdot 41 \\
7 \cdot 38\end{array}$ & $\begin{array}{r}<4 \\
33 \\
<4\end{array}$ & $\begin{array}{l}8 \\
7 \\
9\end{array}$ \\
\hline $3 \underset{\text { Histamine }}{\text { Rest }}$ & $\begin{array}{l}. \\
. .\end{array}$ & $\begin{array}{l}98 \cdot 2 \\
93 \cdot 7 \\
98 \cdot 3\end{array}$ & $\begin{array}{l}15.9 \\
15 \cdot 7 \\
16 \cdot 4\end{array}$ & $\begin{array}{r}71 \\
42 \\
113\end{array}$ & $\begin{array}{l}238 \\
254 \\
480\end{array}$ & $\begin{array}{r}7 \cdot 6 \\
9 \cdot 6 \\
14 \cdot 3\end{array}$ & $\begin{array}{r}5 \cdot 5 \\
6 \cdot 1 \\
11 \cdot 0\end{array}$ & $\begin{array}{l}10 \\
12 \\
18\end{array}$ & $\begin{array}{l}29 \\
30 \\
30\end{array}$ & $\begin{array}{l}7 \cdot 46 \\
7 \cdot 47 \\
7 \cdot 43\end{array}$ & $\begin{array}{l}15 \\
46 \\
10\end{array}$ & $\begin{array}{r}5 \\
6 \\
10\end{array}$ \\
\hline $\begin{array}{c}4 \underset{\text { Rest }}{\text { Ristamine }} \\
\text { Exercise .. } \\
\text { Venesection }\end{array}$ & $\begin{array}{l}. \\
. \\
. \\
.\end{array}$ & $\begin{array}{l}97 \cdot 4 \\
95 \cdot 7 \\
91.9 \\
97 \cdot 0\end{array}$ & $\begin{array}{l}18 \cdot 6 \\
17 \cdot 4 \\
18 \cdot 7 \\
15.9\end{array}$ & $\begin{array}{r}64 \\
41 \\
109 \\
66\end{array}$ & $\begin{array}{l}258 \\
269 \\
680 \\
236\end{array}$ & $\begin{array}{r}7 \cdot 0 \\
7 \cdot 5 \\
18 \cdot 3 \\
6.9\end{array}$ & $\begin{array}{r}4 \cdot 8 \\
4.9 \\
12 \cdot 5 \\
4 \cdot 7\end{array}$ & $\begin{array}{l}13 \\
12 \\
24 \\
15\end{array}$ & $\begin{array}{l}41 \\
41 \\
44 \\
41\end{array}$ & $\begin{array}{l}7 \cdot 45 \\
7 \cdot 44 \\
7 \cdot 39 \\
7 \cdot 44\end{array}$ & $\begin{array}{r}12 \\
21 \\
38 \\
9\end{array}$ & $\begin{array}{r}9 \\
12 \\
15 \\
6\end{array}$ \\
\hline
\end{tabular}

$\mathrm{SaO}_{2}=$ Arterial oxygen saturation $(\%)$

$\mathrm{O}_{2}$ cap $=$ Oxygen capacity $(\mathrm{ml} . / 100 \mathrm{ml}$.)

$(\mathrm{A}-\mathrm{v}) \mathrm{O}_{2}=$ Arteriovenous oxygen difference (ml./l.)

$\dot{\mathrm{VO}}_{2}=$ Oxygen consumption $(\mathrm{ml} . / \mathrm{min}$. STPD)

$\dot{\mathrm{V}} \mathbf{E}=$ Total ventilation $(1 . / \mathrm{min} . \mathrm{BTPS})$

$\dot{\mathrm{V} A}=$ Alveolar ventilation $(1 . / \mathrm{min} . \mathrm{BTPS})$
$\mathrm{RF}=$ Respiratory frequency

$\mathrm{PaCO}_{2}=$ Arterial $\mathrm{CO}_{2}$ tension

$(\mathrm{A}-\mathrm{a}) \mathrm{O}_{2}=$ Alveolar-arterial $\mathrm{O}_{2}$ tension difference $(\mathrm{mm} . \mathrm{Hg})$

$\Delta \mathrm{p}=$ Respiratory pressure variations in the

"PCV" pressure $(\mathrm{mm} . \mathrm{Hg})$

\footnotetext{
- Rest

- Histamine

$\times$ Work
}

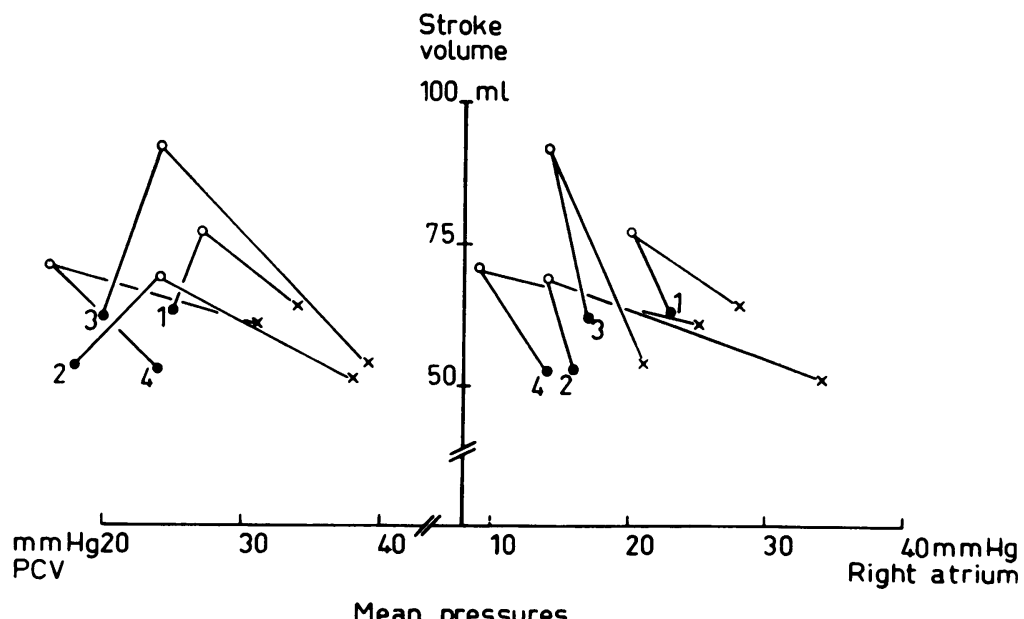

FIG. 1.-The relation between stroke volume (assumed to be the same for both ventricles) and atrial mean pressures at rest, during work, and during an intravenous infusion of histamine. 
the stroke volume. The arteriovenous oxygen difference increased to 94-113 ml./l. The circulation thus became manifestly insufficient at this low work load. The mean pressures in the right atrium and in the PCV position both increased considerably, but the change was somewhat more marked in the PCV pressure. The pulmonary vascular resistance did not change consistently. The arterial oxygen saturation was unchanged during work in Cases 2 and 3 but fell in Cases 1 and 4.

An intravenous infusion of histamine at a rate of $0 \cdot 12-0.39 \mu \mathrm{g}$. histamine base $/ \mathrm{kg}$. body weight/ min. caused flushing of the skin and a decrease in systemic vascular resistance. Cardiac output increased more than during work. This increase was due not only to an increased heart rate but also to a larger stroke volume. The arteriovenous oxygen difference fell. The increase in cardiac output was achieved with a lowered pressure in the right atrium. The PCV pressure rose slightly in three subjects and fell in Case 4. The pulmonary vascular resistance fell. Arterial oxygen saturation decreased by 3.9 per cent on the average. This fall occurred without any significant change in the calculated alveolar ventilation or in the respiratory variations in the PCV pressure. The arterial carbon dioxide tension fell in Case 1 and was unchanged in the others. The alveolar-arterial difference in oxygen tension increased in all cases.

TABLE IV

STROKE WORK OF THE TWO Ventricles*

\begin{tabular}{|c|c|c|c|c|c|}
\hline \multirow{2}{*}{$\begin{array}{c}\text { Case } \\
\text { No. }\end{array}$} & \multirow{2}{*}{ Ventricle } & \multicolumn{4}{|c|}{ Work against pressure in gramme-metres per beat during } \\
\hline & & Rest & Histamine infusion & Exercise & Venesection \\
\hline 1 & Right & $1 \cdot 5$ & $2 \cdot 0$ & $2 \cdot 5$ & - \\
\hline & Left & $8 \cdot 6$ & $8 \cdot 7$ & $8 \cdot 4$ & - \\
\hline 2 & Right & 0.4 & 0.9 & 0.6 & - \\
\hline & Left & $5 \cdot 8$ & $7 \cdot 8$ & $5 \cdot 9$ & - \\
\hline 3 & Right & $1 \cdot 1$ & $2 \cdot 9$ & 1.9 & - \\
\hline & Left & $6 \cdot 8$ & $7 \cdot 1$ & $6 \cdot 3$ & - \\
\hline 4 & $\begin{array}{l}\text { Right } \\
\text { Left }\end{array}$ & $\begin{array}{l}0 \cdot 7 \\
5 \cdot 9\end{array}$ & $\begin{array}{l}1 \cdot 2 \\
6 \cdot 3\end{array}$ & $\begin{array}{l}1 \cdot 9 \\
6 \cdot 6\end{array}$ & $\begin{array}{l}0 \cdot 5 \\
5 \cdot 3\end{array}$ \\
\hline & & & & & \\
\hline
\end{tabular}

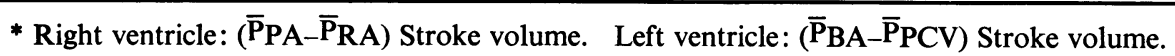

The relation between stroke volume (assumed to be the same for both ventricles) and filling pressure for the two ventricles, at rest, during work, and during histamine infusion are shown in Fig. 1. The figures given in Table II allow calculation of the "work against pressure" per beat of each ventricle, by multiplying the stroke volume with the difference between the mean "output" pressure (aortic or pulmonary mean pressure) and the mean filling pressure (right atrial or PCV pressure). This calculation involves many assumptions, but it may nevertheless be pointed out that the work against pressure per beat of each individual ventricle was always higher during histamine infusion than during rest. In Cases 2 and 3 it was also higher during histamine than during work (Table IV). The effect of a decreased filling pressure was studied in Case 4. Blood was withdrawn until the mean pressure in the right atrium had fallen to $5 \mathrm{~mm}$. Hg and the PCV pressure to $9 \mathrm{~mm}$. $\mathrm{Hg}$, i.e. pressures below those during the histamine infusion. After this venesection there was no significant change in the stroke volume, and the cardiac output decreased.

\section{Discussion}

The observations on the hæmodynamics at rest and during exercise are in agreement with previous findings (e.g. Johansson, 1958; Wood, 1961). The effects of histamine on the circulation and respiration in constrictive pericarditis have apparently not been studied before. The four cases reported here showed uniform and distinct responses to histamine infusions.

The responses to histamine that appear to be of interest are first, the decrease in arterial oxygen 
saturation and increase in alveolar-arterial difference in oxygen tension, and secondly, the increase in cardiac output and stroke volume. The decrease in arterial oxygen saturation cannot be due to a bronchoconstrictor action of histamine since the calculated alveolar ventilation did not decrease, and since there was no significant increase in the respiratory pressure variations. The pulmonary ventilation in chronic constrictive pericarditis is presumably uneven because of vascular engorgement and adhesions between the pericardium, the pleuræ, and the thoracic wall. A normal arterial oxygen saturation can only be maintained if the blood flow through the hypoventilated parts of the lungs is decreased. We regard the decrease in saturation during histamine infusion as a result of vasodilatation and increased blood flow through poorly ventilated parts of the lung. These observations are in accordance with previous studies in asthma and emphysema (Storstein et al., 1959; Helander, Lindell, and Söderholm, 1960). The changes in ventilation-perfusion relations induced by vaso-active substances in patients with cardiopulmonary disease have been discussed elsewhere (Söderholm, 1961; Westling, 1961).

In the present study we wish to focus interest on the property of histamine to increase the cardiac output and stroke volume of the heart. Current opinion regards the low and fixed stroke volume in constrictive pericarditis as due to impeded diastolic filling. It is also possible that the systolic emptying of the ventricles is hindered by anchoring of the pericardium to surrounding structures, e.g. the anterior thoracic wall. It is remarkable that histamine should stimulate the constricted ventricles to a larger stroke volume than such a powerful physiological stimulus as a work load that increases the arteriovenous difference in oxygen content to approximately $100 \mathrm{ml} / .1$.

It is well known that histamine may liberate catechol amines. The stimulation of myocardial contractility under the influence of histamine may be caused by such a liberation. However, the activation of the sympathico-adrenal system in these cases must have been rather intense during the exercise, when their circulation was manifestly insufficient. Yet, the stroke volume was not so large as during histamine infusion. The possibility of another stimulating action of histamine on cardiac muscle than via a liberation of catechol amines must thus be considered. Isaacs, Carter, and Haller (1952) have shown that experimental constrictive pericarditis in the dog changes the pressurevolume curve of the left ventricle, so that a larger pressure increment is necessary for a certain volume change. The volume change for a certain change in pressure also becomes progressively smaller at increasing filling pressure levels. If this applies to the human heart, the increased stroke volume during histamine infusion could be due to a primary reduction of filling pressure caused by, e.g. a change in blood volume distribution or a diminished venous tone. If this was the case one would have to assume that the reduced stroke volume in chronic constrictive pericarditis was caused by the increased venous pressure, and not vice versa. However, the increase in left ventricular stroke volume during histamine took place with a slight increase in filling pressure (PCV pressure). Moreover, venesection with a substantial lowering of filling pressure did not lead to increased ventricular output.

During histamine, there was in three of the cases a lowering of the systemic arterial pressure while the pulmonary arterial pressure was essentially unchanged. It seems unlikely that this moderate lowering of ejection pressure could explain the increase in stroke volume after histamine, and the calculated work against pressure actually increased. This view is also supported by the findings after venesection. Here a lowered systemic and pulmonary arterial pressure did not increase the ventricular output and work against pressure decreased. The possibility of a direct stimulating action of histamine on the cardiac muscle must therefore be considered. Animal experiments have in fact shown that histamine has a direct action on isolated cardiac muscle, increasing both its force and frequency of contraction (Trendelenburg, 1960; Mannaioni, 1960).

Wood (1961) has emphasized that constrictive pericarditis is a "bilateral" disease, and that there are always parallel elevations of the pressure in the right and the left atrium, the latter as estimated by the "PCV pressure." Such a parallelism was also found in the present cases at rest and during exercise, but during the infusion of histamine there was in three of the four cases a decrease in the right atrial pressure concomitantly with a moderate increase in the PCV pressure. This 
differential effect of histamine is difficult to explain at present. If the mechanism of action of histamine in these cases consists of an increase in the contractile power of the heart muscle, one will have to accept the view that impeded ventricular filling is not such a dominant feature in chronic constrictive pericarditis as has been generally supposed. The fact that ventricular output may be increased by pharmacological agents indicates the importance of factors that hinder ventricular emptying.

\section{SUMMARY}

Hæmodynamic observations were made in four men with chronic constrictive pericarditis, who were subjected to heart catheterization.

All four subjects had low stroke volumes at rest and the cardiac output was low in two of them. The right atrial and the PCV pressures were high, but the pulmonary vascular resistance was fairly normal.

During exercise there was only slight increase in cardiac output and the arteriovenous difference in oxygen content of the blood increased to high values. The right atrial and PCV pressures increased considerably.

During an intravenous infusion of histamine the cardiac output and the stroke volume increased, and were higher than during exercise. The calculated stroke work was also increased by histamine. During histamine infusion the right atrial pressure decreased, and the PCV pressure increased, but comparatively little.

The mechanism of this effect of histamine is discussed and it is concluded that a direct action of histamine on the heart, with an increase of its contractile power, is the most likely explanation.

We wish to thank Dr. N. P. Bergh, Head of the Department of Thoracic Surgery, for making the operative findings available, and Nurse Anna-Greta Kindström for expert assistance at the cardic catheterizations.

\section{REFERENCES}

Arenander, E., Carlsten, A., Grimby, G., Hallberg, L., and Westling, H. (1962). Scand. J. clin. Lab. Invest., 14, 170. Bernéus, B., Carlsten, A., Holmgren, A., and Seldinger, S. I. (1954). Scand. J. clin. Lab. Invest., 6, 217.

Carlsten, A., and Söderholm, B. (1960). Acta physiol. scand., 48, 29.

Grimby, G., and Söderholm, B. (1963). Acta med. scand. In press.

Helander, E., Lindell, S.-E., and Söderholm, B. (1960). Poumon, 16, 1087.

Isaacs, J. P., Carter, B. N., and Haller, J. A. (1952). Bull. Johns Hopk. Hosp., 90, 259.

Johansson, L. (1958). Surgical Treatment of Chronic Constrictive Pericarditis. PA Norstedt and Söner, Stockholm. Mannaioni, P. F. (1960). Brit. J. Pharmacol., 15, 500.

Rahn, H., and Fenn, W. O. (1955). A graphical analysis of the respiratory gas exchange. Amer. Physiol. Soc., Washington D.C.

Söderholm, B. (1957). Scand. J. clin. Lab. Invest., Suppl. 26.

(1962). Proc. First. Internat. Pharmacol. Meeting, 1961.

Storstein, O., Calabresi, M., Nims, R. G., and Gray, F. D. (1959). Y Yale J. Biol. Med., $32,197$.

Trendelenburg, U. (1960). J. Pharmacol. exp. Ther., 130, 450.

Westling, H. (1962). Proc. First Internat. Pharmacol. Meeting, 1961.

Wood, P. (1961). Amer. J. Cardiol., 7, 48.

Zimmerman, H. A. (1959). Intravascular Catheterization. Thomas Springfield, Illinois. 